\title{
JOANNA MAY
}

Uniwersytet Mikołaja Kopernika

\section{CYWILNOPRAWNA ODPOWIEDZIALNOŚĆ ODSZKODOWAWCZA PRACODAWCY ZA WYPADEK PRZY PRACY}

\section{WPROWADZENIE}

Z ustawy o ubezpieczeniu społecznym z tytułu wypadków przy pracy i chorób zawodowych ${ }^{1}$ wynika, że pracownikowi poszkodowanemu w wyniku wypadku przy pracy przysługuje między innymi jednorazowe odszkodowanie lub renta $\mathrm{z}$ tytułu niezdolności do pracy (art. 6 pkt 4 i 6 ustawy wypadkowej). Jeżeli zaś konsekwencją wypadku przy pracy jest śmierć pracownika, to członkowie jego rodziny są uprawnieni do jednorazowego odszkodowania lub renty rodzinnej (art. 13 ust. $1 \mathrm{i}$ art. 17 ust. 5 ustawy wypadkowej). Świadczenia te, zgodnie z zasadami określonymi w art. 10 ust. 2 ustawy wypadkowej, wypłaca Zakład Ubezpieczeń Społecznych.

Nie oznacza to jednak, że opłacanie składek na ubezpieczenie wypadkowe zwalnia pracodawcę z odpowiedzialności z tytułu wypadku przy

1 Ustawa z 30 października 2002 r. o ubezpieczeniu społecznym z tytułu wypadków przy pracy i chorób zawodowych (tekst jedn.: Dz. U. z 2018 r. poz. 1376), dalej: ustawa wypadkowa. 
pracy $^{2}$. Pracownik poszkodowany podczas takiego wypadku bądź osoby poszkodowane wskutek śmierci pracownika mogą bowiem dochodzić od pracodawcy uzupełniających świadczeń na zasadach określonych w kodeksie cywilnym ${ }^{3}$. Warto jednak zauważyć, że uznanie zdarzenia za wypadek przy pracy nie oznacza automatycznie, że zdarzenie to będzie rodziło cywilnoprawną odpowiedzialność pracodawcy. Czym innym jest bowiem uznanie zdarzenia za wypadek przy pracy, czym innym zaś ustalenie odpowiedzialności pracodawcy za to zdarzenie. Może również zaistnieć taka sytuacja, że wypadek przy pracy będzie rodził nie tylko odpowiedzialność odszkodowawczą pracodawcy, lecz także odpowiedzialność karną. Niejednokrotnie bowiem między sprawą karną a cywilną zachodzi związek tego rodzaju, że ten sam czyn stanowi przestępstwo, wywołując jednocześnie skutki w sferze prawa cywilnego w postaci odpowiedzialności odszkodowawczej.

2 W okresie od 1 stycznia 1968 r. do 31 grudnia 1989 r. (pierwotnie na podstawie art. 22 ustawy wypadkowej z 23 stycznia 1968 r., Dz. U. Nr 3, poz. 6 ze zm., a następnie na podstawie art. 40 ustawy wypadkowej z 12 czerwca 1975 r., tekst jedn.: Dz. U. z 1983 r. Nr 30, poz. 144) uznawano, że świadczenia z ustawy wypadkowej zaspokajają wszelkie roszczenia pracownika w stosunku do zakładu pracy. Por. uchwała SN z 24 października 1986 r., III PZP 59/86, «Legalis» nr 25556; J. BROL, Uprawnienia pracownicze w razie wypadku przy pracy i choroby zawodowej, Bydgoszcz 1991, s. 60. Por. też U. JАСКОWIAK, Wyrównywanie szkód niemajątkowych spowodowanych wypadkami przy pracy, Warszawa-Poznań 1975, s. 17 oraz s. 104 i n. Poglądy te uległy zmianie z dniem 1 stycznia 1990 r., a więc gdy stracił moc art. 40 ustawy wypadkowej z 12 czerwca 1975 r. (Dz. U. Nr 36, poz. 206), wyrażający zakaz dochodzenia roszczeń z tytułu uszczerbku na zdrowiu wskutek wypadku przy pracy lub choroby zawodowej ponad świadczenia określone w ustawie; tak M. RAczKowski, Kilka uwag o cywilnej odpowiedzialności odszkodowawczej pracodawcy, «PiZS» 4/2009, s. 3.

3 M. Gersdorf, Odpowiedzialność cywilnoprawna pracodawcy za wypadki przy pracy, «PiZS» 6/2003, s. 9 i n., zwraca uwagę, że zmiany ustawy wypadkowej, dokonane ustawą z 24 maja 1990 r. (Dz. U. Nr 36, poz. 206), w wyniku których dopuszczalne stało się dochodzenie roszczeń uzupełniających od pracodawcy na zasadach prawa cywilnego, zostały dokonane bez wyważenia interesów pracodawców, co stwarza ryzyko nadmiernego obciążenia zwłaszcza małego i średniego pracodawcy. Zob. też W. Sanetra W., Nowa filozofia wypadkowa, «Przegląd Ubezpieczeń Społecznych i Zdrowotnych»11/2002, s. 2. 
Celem artykułu jest zarysowanie procesowych i materialnoprawnych aspektów związanych z odpowiedzialnością odszkodowawczą pracodawcy. Zagadnienia materialnoprawne jednak przedstawione zostały jedynie $\mathrm{w}$ zakresie niezbędnym do zaprezentowania tytułowego zagadnienia.

\section{CHARAKTER ODPOWIEDZIALNOŚCI PRACODAWCY}

Ożywioną dyskusję w nauce wywołały zmiany dokonane w ustawie wypadkowej ${ }^{4}$, które umożliwiły pracownikom, poszkodowanym w wyniku wypadku przy pracy, na występowanie z roszczeniami uzupełniającymi w stosunku do pracodawcy ${ }^{5}$. Jak bowiem wskazywano, trudno pogodzić przyjęty w ustawie wypadkowej system łatwych do realizacji roszczeń pracowniczych, uniezależnionych od winy pracodawcy czy konieczności wykazania szkody, czego konsekwencją jest ryczałtowy charakter odszkodowania, z odpowiedzialnością na zasadach prawa cywilnego. Cywilnoprawna odpowiedzialność odszkodowawcza zakłada pełną odpowiedzialność za szkodę, ale z wszelkimi płynącymi z tego konsekwencjami, chociażby $\mathrm{w}$ postaci sprostania przez pracownika ciężarowi dowodu w zakresie wykazania przesłanek odpowiedzialności odszkodowawczej $j^{6}$.

W literaturze przedmiotu pojawiły się także różne koncepcje w zakresie oceny charakteru odpowiedzialności pracodawcy za wypadek przy pracy, a więc czy jest to odpowiedzialność deliktowa, czy kontraktowa ${ }^{7}$.

4 Chodzi o uchylenie art. 40 ustawy wypadkowej z 12 czerwca 1975 r. (Dz. U. Nr 36, poz. 206).

5 Za dopuszczalnością takich rozwiązań opowiadali się m.in. E. MANiEwsKA, Jeszcze o odpowiedzialności cywilnoprawnej pracodawcy za wypadki przy pracy, «PiZS» 12/2011, s. 21; W. Ostaszewski, Charakter odpowiedzialności uzupełniającej pracodawcy a deliktowy reżim odpowiedzialności cywilnej, «PiZS» 6/2013, s. 2 i n. Por. też J. JońCZYк, Ubezpieczenie wypadkowe, «PiP»58.6/2003, s. 3 i n. Odmienne zapatrywanie prezentowali m.in. M. Gersdorf, Odpowiedzialność..., s. 9 i n.; M. RACZKowski, Kilka uwag..., s. 4 i n.

6 Bliżej M. Gersdorf, Odpowiedzialność..., s. 10 i n.

7 Por. m.in. M. Gersdorf, Odpowiedzialność..., s. 10 i n.; M. RACZKowski, Zadośćuczynienie jako sankcja w odpowiedzialności kontraktowej z perspektywy prawa pracy, 
Ze stanowiska przedstawicieli doktryny oraz z orzecznictwa wynika, że oba reżimy nie wykluczają się wzajemnie ${ }^{8}$. Podstawę prawną roszczeń pracownika może stanowić zarówno art. 471 k.c., jak i art. 415, 444 oraz 445 k.c. Przy zbiegu odpowiedzialności poszkodowany pracownik powinien wybrać jeden $\mathrm{z}$ reżimów odpowiedzialności ${ }^{9}$. Stosownie do art. 443 k.c. okoliczność, że działanie lub zaniechanie, z którego szkoda wynikła, stanowiło niewykonanie lub nienależyte wykonanie istniejącego uprzednio zobowiązania, nie wyłącza roszczenia o naprawienie szkody z tytułu czynu niedozwolonego, chyba że z treści istniejącego uprzednio zobowiązania wynika co innego.

\section{DELIKTOWY REŻIM ODPOWIEDZIALNOŚCI PRACODAWCY}

Zgodnie z ugruntowanym stanowiskiem Sądu Najwyższego dopuszczalne jest dochodzenie przez pracownika od pracodawcy roszczeń uzupełniających z tytułu wypadków przy pracy, opartych na przepisach prawa cywilnego (art. 415, 444 i 445 k.c. w zw. z art. 300 k.p.) ${ }^{10}$. Odpowiedzialność odszkodowawcza pracodawcy za szeroko rozumianą szkodę, powstałą w wyniku wypadku przy pracy, może kształtować się zarówno na zasadzie winy, jak i ryzyka ${ }^{11}$.

«PPH» 12/2011, s. 52 i n. Por. też wyrok SN z 14 grudnia 2010 r., I PK 95/10, «Legalis» nr 414600.

8 Wyrok SN z 13 września 2016 r., III PK 146/15, «OSP» 5/2017, poz. 51, z częściowo krytyczną glosą T. Liszcz, s. 122 i n. Por. też J. Jończy K, Odpowiedzialność odszkodowawcza w prawie pracy, «PiP» 58.6/2003, s. 746 i n.; T. LIszcz, Odpowiedzialność odszkodowawcza pracodawcy wobec pracownika, cz. 1, «PiZS»12/2008, s. 3.

9 Tak T. Liszcz, Odpowiedzialność odszkodowawcza pracodawcy wobec pracownika, cz. 2, «PiZS»1/2009, s. 6 i n.

10 Wyrok SN z 5 lipca 2005 r., I PK 293/04, «Legalis» nr 71141; uchwała SN z 9 stycznia 2018 r., III PZP 3/17, «Legalis» nr 1705314; wyrok SN z 8 listopada 2018 r., III PZP 4/18, «Legalis» nr 1847144.

${ }^{11}$ W nauce prezentowane są poglądy, którym trudno odmówić racji, że pracodawca - z tytułu łączącego strony stosunku pracy - za naruszenie zasad bezpieczeństwa i higieny pracy powinien ponosić odpowiedzialność kontraktową (art. 471 k.c.); tak 
Kodeks cywilny jako podstawową zasadę odpowiedzialności ustanawia odpowiedzialność na zasadzie winy (art. 415 k.c.). Zasada ta będzie stanowiła źródło odpowiedzialności, gdy wypadek przy pracy wystąpił na skutek zawinionego działania bądź zaniechania ${ }^{12}$. Z kolei odpowiedzialność na zasadzie ryzyka wchodzi w rachubę, gdy wyrządzona pracownikowi szkoda na osobie lub mieniu powstała w wyniku działania przedsiębiorstwa lub zakładu wprawianego w ruch za pomocą sił przyrody (pary, gazu, elektryczności, paliw płynnych itp.), chyba że szkoda powstała wskutek siły wyższej lub wyłącznie z winy poszkodowanego lub osoby trzeciej, za którą pracodawca nie ponosi odpowiedzialności (art. 435 k.c.) ${ }^{13}$. Zwolnienie $\mathrm{z}$ odpowiedzialności jest możliwe w powołaniu na przesłanki egzoneracyjne, na przykład wykazanie wyłącznej winy pracownika ${ }^{14}$. Ten zaostrzony reżim odpowiedzialności odszkodowawczej odnosi się do tych pracodawców, którzy w swej działalności wykorzystują siły przyrody, z założenia stanowiące zwiększone zagrożenie (np. zakłady energetyczne, transportowe, budowlane, kopalnie, huty itp. $)^{15}$.

M. Gersdorf, Odpowiedzialność..., s. 9 i n.; M. RaCzKowski, Kilka uwag..., s. 4 i n.; IDEM, Zadośćuczynienie..., s. 52 i n.

12 Wyrok SN z 4 listopada 2008 r., II PK 100/08, «Legalis» nr 223241.

13 Odpowiedzialność pracodawcy na zasadzie ryzyka oparta jest na założeniu, że samo funkcjonowanie zakładu wprawianego w ruch za pomocą sił przyrody stwarza niebezpieczeństwo wyrządzenia szkody, niezależnie od działania lub zaniechania prowadzącego taki zakład. Zakresem przedmiotowym art. 435 k.c. objęte są tylko takie przedsiębiorstwa, które dla prawidłowego funkcjonowania (dla osiągnięcia zakładanych celów) muszą opierać swą działalność na wykorzystaniu odpowiednio przetworzonych sił przyrody (pary, gazu, elektryczności itp.). Muszą być to zarazem siły odpowiednio przetworzone za pomocą różnego rodzaju maszyn i urządzeń mechanicznych; tak SA w Lublinie w wyroku z 19 grudnia 2018 r., III APa 16/18, «Legalis» nr 1865490.

14 Wyrok SN z 9 kwietnia 2008 r., II PK 283/07, «Legalis» nr 177624; wyrok SN z 7 stycznia 2010 r., II PK 132/09, «Legalis» nr 336552.

15 R. SAdLIK, Zadośćuczynienie w razie wypadku przy pracy, «Monitor Prawa Pracy» 9/2014, s. 469 i n. Zastosowana jako źródło energii „siła przyrody” w rozumieniu art. $435 \$ 1$ k.c. powinna stanowić siłę napędową, od której zależy funkcjonowanie przedsiębiorstwa (zakładu) jako całości. Kluczowe jest zatem badanie w okolicznościach konkretnego przypadku, czy działalność wprawiana w ruch za pomocą sił przyrody 


\section{Przesłanki odPowiedzialności odszKodowaWCZEJ PRACODAWCY}

Do powstania odpowiedzialności odszkodowawczej na zasadach określonych w kodeksie cywilnym nie wystarczy uznanie zdarzenia za wypadek przy pracy lub samo powstanie szkody, w przeciwieństwie do świadczeń z ustawy wypadkowej, kiedy to na przykład jednorazowe odszkodowanie przysługuje w razie zaistnienia zdarzenia objętego ubezpieczeniem.

Pracownik, występując przeciwko pracodawcy z roszczeniem odszkodowawczym z powodu szkody doznanej wskutek niezapewnienia bezpiecznych warunków pracy, nie może w postępowaniu sądowym powołać się jedynie na fakt zaistnienia wypadku przy pracy, który stwierdzony został protokołem powypadkowym, ale musi wykazać przesłanki odpowiedzialności odszkodowawczej ${ }^{16}$. W zależności więc od rodzaju odpowiedzialności deliktowej, pracownik przy odpowiedzialności ukształtowanej na zasadzie winy powinien wykazać kumulatywne wystąpienie przesłanek odpowiedzialności, tj. zawinionego (bezprawnego) ${ }^{17}$ zachowania się sprawcy szkody (mogącego przybrać postać działania lub zaniechania - chodzi o zaniechanie działania, do którego podjęcia dany podmiot był w świetle prawa zobowiązany); powstania szkody (rozumianego jako uszczerbek w dobrach majątkowych lub niemajątkowych) po stronie podmiotu innego niż sprawca szkody oraz istnienie zwyczajnego (tzw. adekwatnego) związku przyczynowo-skutkowego między zawinionym (bezprawnym) zachowaniem się danego podmiotu a powstaniem szkody u drugiego podmiotu, rozumiane jako sytuacja, w której zachowanie się sprawcy szkody stanowiło warunek konieczny

jest dla danego przedsiębiorstwa zasadnicza, czy tylko wspomagająca. Por. wyrok SN z 18 grudnia 2018 r., IV CSK 483/17, «Legalis» nr 1875429.

16 Por. wyrok SN z 5 lipca 2005 r., I PK 293/04, «Legalis» nr 71141.

17 Tradycyjnie przyjmuje się, że wina składa się z dwóch elementów: obiektywnego określanego mianem bezprawności oraz subiektywnego określanego niekiedy mianem winy sensu stricto; wyrok SN z 13 września 2016 r., III PK 146/15, «OSP» 5/2017, poz. 51. 
(conditio sine qua non) zaistnienia szkody ${ }^{18}$. Natomiast w przypadku odpowiedzialności na zasadzie ryzyka pracownik nie ma obowiązku wykazywania, że działanie bądź zaniechanie pracodawcy było zawinione, musi jednak udowodnić szkodę (uszczerbek na zdrowiu) i związek przyczynowy pomiędzy zdarzeniem będącym wypadkiem przy pracy a powstaniem szkody ${ }^{19}$. Na pracowniku spoczywa w tym zakresie ciężar dowodu (art. 6 k.c.).

\section{SUBSYDIARNY CHARAKTER ODPOWIEDZIALNOŚCI PRACODAWCY ZA WYPADEK PRZY PRACY}

Sąd Najwyższy wielokrotnie wskazywał na dopuszczalność dochodzenia roszczeń uzupełniających w stosunku do świadczeń wynikających

18 Wyrok SN z 13 września 2016 r., III PK 146/15, «OSP» 5/2017, poz. 51. Powinnością pracodawcy jest nie tylko zapoznanie pracownika z ogólnymi przepisami oraz zasadami bezpieczeństwa i higieny pracy, lecz także zwrócenie uwagi na konkretne zagrożenia występujące na stanowisku pracy, na którym pracownik będzie wykonywał swoje obowiązki. Chodzi przy tym o zagrożenia typowe, a w każdym razie możliwe do przewidzenia, a nie zagrożenia szczególne, wyjątkowe, mogące wystąpić w sytuacjach nietypowych. Odpowiedzialność pracodawcy na zasadzie winy za skutki wypadku przy pracy uwarunkowana jest wykazaniem przez pracownika w toku procesu, że tego rodzaju działań zaniechano albo dokonano ich niewłaściwie. Konieczne jest zatem stwierdzenie, że w konkretnych okolicznościach faktycznych praca została zorganizowana nieprawidłowo, co w konsekwencji doprowadziło do wypadku, albo $\dot{z}$ e istniejące realne zagrożenia przy jej wykonywaniu nie zostały rozpoznane przez pracodawcę, wobec czego pracownik nic o nich nie wiedział, albo zagrożenia faktycznie rozpoznane nie zostały wyeliminowane przez pracodawcę, co naraziło na uszczerbek zdrowie pracownika. Tak SN w wyroku z 7 stycznia 2010 r., II PK 132/09, «Legalis» nr 336552.

19 W procesie o odszkodowanie od pracodawcy, którego odpowiedzialność jako prowadzącego przedsiębiorstwo wprawiane w ruch siłami przyrody, oparta jest na zasadzie ryzyka (art. $435 \$ 1$ k.c.), zbędne jest rozważanie, czy można mu przypisać zawinienie lub bezprawne zaniedbania w zakresie obowiązków dotyczących stworzenia bezpiecznych i higienicznych warunków pracy. Tak SN w wyroku z 14 lutego 2002 r., I PKN 853/00, LEX nr 54886. 
z ustawy wypadkowej ${ }^{20}$. Powstaje pytanie, jak należy rozumieć ową uzupełniającą czy inaczej subsydiarną odpowiedzialność pracodawcy ${ }^{21}$. Odwołując się do dorobku judykatury, warto przedstawić dwa znaczenia nadawane pojęciu uzupełniającej odpowiedzialności pracodawcy ${ }^{22}$. Zgodnie z pierwszym pracownik może dochodzić swoich roszczeń przeciwko pracodawcy, jeśli nie zostały one w pełni zaspokojone przez wypłatę świadczeń przysługujących z ZUS na podstawie ustawy wypadkowej23. W drugim znaczeniu zaś pracodawca ponosi odpowiedzialność wyłącznie po uprzednim rozpoznaniu roszczeń pracownika o świadczenia z ubezpieczenia wypadkowego i w wysokości, w jakiej świadczenia $\mathrm{z}$ ubezpieczenia wypadkowego nie pokryły doznanego przez pracownika uszczerbku ${ }^{24}$.

Przyjęcie subsydiarnego charakteru odpowiedzialności pracodawcy w drugim z przedstawionych znaczeń ma wpływ, po pierwsze, na czas dochodzenia przez pracownika roszczeń wobec pracodawcy, po drugie zaś, na ich wysokość.

Odnosząc się do aspektu czasowego, wytoczenie powództwa przeciwko pracodawcy o odszkodowanie lub rentę dopuszczalne jest zatem dopiero po rozpoznaniu prawa pracownika do jednorazowego odszkodowania z tytułu stałego lub długotrwałego uszczerbku na zdrowiu lub

20 Tak m.in. SN w uchwale siedmiu sędziów z 14 grudnia 1990 r., III PZP 20/90, «Legalis» nr 27173, oraz w wyroku z 27 listopada 2018 r., I PK 208/17, «Legalis» nr 1851038.

${ }^{21}$ SN w wyroku z 29 lipca 1998 r. wskazywał na istnienie uzupełniającej odpowiedzialności pracodawcy, II UKN 155/98, «Lex» nr 37000.

22 Por. wyroki SN: z 29 lipca 1998 r., II UKN 155/98, «Lex» nr 37000, oraz z 9 lipca 2015 r., I PK 243/14, «Legalis» nr 1351527.

23 Wyroki SN z 5 lipca 2005 r., I PK 293/04, «Legalis» nr 71141, oraz z 5 września 2017 r., II PK 206/16, «Legalis» nr 1696687.

24 Cywilnoprawna odpowiedzialność pracodawcy za skutki wypadku przy pracy ma charakter uzupełniający. Pracownik nie może dochodzić odszkodowania i renty na podstawie art. 444 k.c. przed rozpoznaniem jego roszczeń o świadczenia przysługujące na podstawie przepisów ustawy z 12 czerwca 1975 r. o świadczeniach z tytułu wypadków przy pracy i chorób zawodowych. Tak SN w wyroku z 29 lipca 1998 r., II UKN 155/98, «Lex» nr 37000. Podobnie SN w postanowieniu z 13 grudnia 2018 r., I PK 259/17, «Legalis» nr 1855916. Por. też B. NAróG, Odszkodowania za wypadki przy pracy w postępowaniach cywilnoprawnych, «Praca i Zdrowie» 3/2015, s. 48. 
renty z tytułu niezdolności do pracy na podstawie przepisów ustawy wypadkowej. Wynika to z ryczałtowego charakteru świadczeń z ustawy wypadkowej, które są limitowane co do wysokości, zaś odpowiedzialność cywilnoprawna pracodawcy ma jedynie charakter uzupełniający. Należy jednak podkreślić, że cywilnoprawna podstawa odpowiedzialności pracodawcy powstaje dopiero wówczas, gdy świadczenia z ustawy wypadkowej nie rekompensują w całości poniesionej przez poszkodowanego pracownika szkody i równocześnie są spełnione przesłanki odpowiedzialności odszkodowawczej.

Pracownik może więc dochodzić odszkodowania i renty na podstawie przepisów kodeksu cywilnego dopiero, gdy zostaną rozpoznane jego roszczenia o te świadczenia na podstawie przepisów ustawy wypadkowej ${ }^{25}$. Natomiast w razie wytoczenia powództwa przeciwko pracodawcy o odszkodowanie lub rentę bądź też o oba świadczenia łącznie, należałoby uznać je za przedwczesne i na tej podstawie oddalić ${ }^{26}$. Oddalenie powództwa jako przedwczesnego nie zamyka jednak pracownikowi drogi do późniejszego dochodzenia roszczeń uzupełniających po uzyskaniu jednorazowego odszkodowania lub renty $z$ ubezpieczenia wypadkowego. W tym wypadku powaga rzeczy osądzonej nie stałaby na przeszkodzie dochodzeniu roszczenia, oczywiście dopiero po uprzednim uzyskaniu świadczeń z ustawy wypadkowej (art. 366 k.p.c.).

Jeśli zaś chodzi o zakres roszczeń pracownika, to jest on uprawniony do dochodzenia roszczeń uzupełniających od pracodawcy z tytułu wypadku przy pracy wyłącznie w takiej wysokości, w jakiej nie zostały one pokryte $\mathrm{z}$ ubezpieczenia społecznego. W przeciwieństwie bowiem do świadczeń z ubezpieczenia wypadkowego, wysokość uzupełniających roszczeń o charakterze cywilnoprawnym nie ma charakteru ryczałtowego, ponieważ jest uzależniona od okoliczności konkretnego przypadku i wielkości szkody poniesionej przez pracownika. W tym miejscu można odwołać się do bogatego dorobku orzeczniczego, który

25 Por. J. Brol, Odpowiedzialność odszkodowawcza za wypadki przy pracy i choroby zawodowe, Warszawa 1981, s. 184 i n.

26 Tak w uzasadnieniu SN w wyroku z 29 lipca 1998 r., II UKN 155/98, «Lex» nr 37000. Pogląd ten reprezentował również SN w orzeczeniach z 10 lutego 1955 r., II CR 266/55, «Lex» nr 118701, oraz z 5 listopada 1952 r., C 21/52, «Lex» nr 292929. 
dostarcza wielu cennych przykładów okoliczności mających wpływ na wysokość odszkodowania czy zadośćuczynienia ${ }^{27}$.

Przedstawione rozumienie subsydiarnej odpowiedzialności pracodawcy jest raczej odosobnione $e^{28}$, dominujący natomiast $\mathrm{w}$ doktrynie i judykaturze jest pierwszy z prezentowanych poglądów, co oznacza, że uzupełniający charakter roszczeń pracownika $\mathrm{w}$ stosunku do pracodawcy będzie miał wpływ jedynie na wysokość należnych pracownikowi świadczeń ${ }^{29}$. Odpowiedzialność cywilnoprawna pracodawcy za wypadek przy pracy jest bowiem niezależna od tej, którą ponosi Zakład Ubezpieczeń Społecznych na mocy ustawy wypadkowej. Odmienne są zasady i zakres tej odpowiedzialności - w przeciwieństwie bowiem do odpowiedzialności organu rentowego, odpowiedzialność cywilnoprawna pracodawcy nie jest w żaden sposób limitowana i jej zakres jest wyznaczany wielkością poniesionej przez pracownika szkody ${ }^{30}$.

Słusznie zauważa Ryszard Sadlik, że niedopuszczalne jest uzależnianie możliwości wytoczenia powództwa o naprawienie szkody od uprzedniego wystąpienia do ZUS z wnioskiem o świadczenia z ubezpieczenia wypadkowego. Po pierwsze dlatego, że nie znajduje to oparcia w przepisach prawa, po drugie zaś na przeszkodzie zgłoszeniu roszczeń

27 Por. m.in. wyrok SA w Szczecinie z 23 sierpnia 2017 r., I ACa 577/16, «Legalis» nr 1696474; wyrok SA w Warszawie z 7 listopada 2017 r., V ACa 172/17, «Legalis» nr 1696422; wyrok SN z 21 września 2017 r., I PK 272/16, «Legalis» nr 1695956.

28 Wyrok SN z 29 lipca 1998 r., II UKN 155/98, «Lex» nr 37000; postanowienie SN z 13 grudnia 2018 r., I PK 259/17, «Legalis» nr 1855916; B. NARÓG, Odszkodowania..., s. 48 in.

29 Jak wyjaśnił Sąd Najwyższy w jednej z uchwał, niezgłoszenie przez pracownika roszczeń przysługujących z ubezpieczenia społecznego nie stoi na przeszkodzie wytoczeniu powództwa przeciwko pracodawcy z tytułu odpowiedzialności cywilnoprawnej. Świadczenia z ubezpieczenia wypadkowego mogą jednak mieć znaczenie dla ustalenia wysokości odpowiedzialności odszkodowawczej pracodawcy, wówczas sąd może zawiesić postępowanie w sprawie o zadośćuczynienie ze względu na inne toczące się postępowanie. SN zauważa także, że tylko w wyjątkowych okolicznościach brak decyzji w kwestii renty ubezpieczeniowej będzie dawać podstawę do zawieszenia postępowania, gdyż nie zachodzi tu wymaganie odliczenia świadczeń z ustawy wypadkowej od sumy zadośćuczynienia, lecz co najwyżej potrzeba ich uwzględnienia w pewnym stopniu. Tak SN w uchwale z 11 lutego 1963 r., II PO 6/62, «Lex» nr 104901.

30 Wyrok SN z 5 września 2017 r., II PK 206/16, «Legalis» nr 1696687. 
mogą stać przeszkody natury faktycznej (np. niezakończony proces leczenia) lub prawnej, które uniemożliwiają pracownikowi wystąpienie z wnioskiem do ZUS ${ }^{31}$.

W nauce i orzecznictwie w pełni aprobowane jest zapatrywanie, że przepisy kodeksu cywilnego mogą być podstawą samodzielnego roszczenia ${ }^{32}$. Uzupełniający charakter odpowiedzialności pracodawcy oznacza jedynie, że wynik postępowania o świadczenia z ubezpieczenia społecznego prowadzonego na podstawie ustawy wypadkowej i tym samym uzyskane przez pracownika z tego tytułu świadczenia będą miały wpływ na postępowanie cywilne dotyczące odpowiedzialności odszkodowawczej pracodawcy, a przede wszystkim na ocenę rozmiaru szkody i w konsekwencji na wysokość świadczeń uzupełniających. Przesłanką warunkującą wytoczenie powództwa o odszkodowanie czy zadośćuczynienie w stosunku do pracodawcy z pewnością nie jest uprzednie dochodzenie przez pracownika świadczeń z ustawy wypadkowej. Orzeczenia organów rentowych nie wiążą sądu powszechnego ${ }^{33}$.

Niezależnie jednak od powyższej argumentacji każdorazowo, oczywiście $\mathrm{z}$ uwzględnieniem okoliczności faktycznych sprawy, warte rozważenia jest zawieszenie postępowania o roszczenia $z$ art. 444 i 445 k.c. do czasu zakończenia postępowania przed Zakładem Ubezpieczeń

31 R. SAdLik, Zadośćuczynienie..., s. 468 i n.

32 Podstawą prawną dochodzenia tego samodzielnego roszczenia będą przepisy kodeksu cywilnego w związku z art. 300 k.p., który w sprawach nieunormowanych przepisami prawa pracy odsyła do odpowiedniego stosowania przepisów kodeksu cywilnego, jeżeli nie są one sprzeczne z zasadami prawa pracy. Tak m.in. SN w wyroku z 4 listopada 2008 r., II PK 100/08, «Legalis» nr 223241. T. Liszcz, Odpowiedzialność..., cz. 2, s. 7 i n. W uchwale z 9 stycznia 2018 r., III PZP 3/17 (Legalis nr 1705314) Sąd Najwyższy stwierdził, że w prawie pracy nie ma zamkniętej liczby roszczeń. Podstawy prawne roszczeń określone w kodeksie pracy przewidziane są dla sytuacji zwykłych i typowych. W kwestiach nieuregulowanych w kodeksie pracy bądź w zakresie roszczeń uzupełniających nie jest wyłączona odpowiedzialność odszkodowawcza pracodawcy na zasadach przewidzianych w kodeksie cywilnym (art. 415, 471 k.c. w zw. z art. 300 k.p.); tak też SN w wyroku z 8 listopada 2018 r., III PZP 4/18, «Legalis» nr 1847144. Bliżej na temat zastosowania art. 300 k.p. K. ŚLEBZAK, Uzupełniająca odpowiedzialność pracodawcy $z$ tytułu wypadków przy pracy i chorób zawodowych, «PiZS» 11/2009, s. 4 i n.

33 Wyrok SN z 19 maja 1969 r., II PR 159/69, «OSNC» 1970/4, poz. 64. 
Społecznych (art. $177 \$ 1$ pkt 3 k.p.c.) lub wyznaczenie terminu do wszczęcia takiego postępowania (art. $177 \$ 2$ k.p.c.). Możliwe jest także samodzielne ustalenie przez sąd prowadzący postępowanie o świadczenia uzupełniające, czy spełnione zostały przez pracownika przesłanki prawa do świadczeń z ubezpieczenia wypadkowego oraz ewentualnie jaka będzie ich wysokośćc ${ }^{34}$.

\section{ROSZCZENIA PRACOWNIKA W STOSUNKU DO PRACODAWCY ORAZ CZYNNIKI MAJĄCE WPŁYW NA ICH ZAKRES}

Obok świadczeń przysługujących pracownikowi lub członkom jego rodziny z ustawy wypadkowej (art. 6) pracownik może również dochodzić na zasadach ogólnych roszczeń z tytułu cywilnoprawnej odpowiedzialności pracodawcy ${ }^{35}$. Jeżeli zatem w następstwie wypadku przy pracy doszło do uszkodzenia ciała lub wywołania rozstroju zdrowia, to naprawienie szkody obejmuje wszystkie koszty wynikłe w konsekwencji doznanej szkody. Będą to między innymi suma potrzebna na koszty leczenia, a jeżeli poszkodowany stał się inwalidą, także suma potrzebna na koszty przygotowania do innego zawodu. Jeśli poszkodowany pracownik utracił całkowicie lub częściowo zdolność do pracy zarobkowej albo jeżeli zwiększyły się jego potrzeby lub zmniejszyły widoki powodzenia na przyszłość, może on żądać odpowiedniej renty (art. 444 k.c. w zw. z art. 300 k.p.). Sąd może także przyznać poszkodowanemu odpowiednią sumę tytułem zadośćuczynienia pieniężnego za doznaną krzywdę (art. $445 \$ 1$ k.c. $w$ zw. $z$ art. 300 k.p.).

Z orzecznictwa sądów powszechnych i Sądu Najwyższego jawi się spójny obraz wypracowanych przez judykaturę okoliczności, które mają wpływ na wysokość odszkodowania czy zadośćuczynienia ${ }^{36}$. W razie uszkodzenia ciała i rozstroju zdrowia sądy uwzględniają czynniki

34 Wyrok SN z 5 września 2017 r., II PK 206/16, «Legalis» nr 1696687.

35 Wyrok SN z 5 lipca 2005 r., I PK 293/04, «Legalis» nr 71141.

36 Wyrok SA w Szczecinie z 23 sierpnia 2017 r., I ACa 577/16, «Legalis» nr 1696474; wyrok SA w Warszawie z 7 listopada 2017 r., V ACa 172/17, «Legalis» nr 1696422; wyrok SN z 21 września 2017 r., I PK 272/16, «Legalis» nr 1695956. 
obiektywne, takie jak czas trwania, stopień intensywności cierpień fizycznych i psychicznych, nieodwracalność skutków urazu (kalectwo, oszpecenie), rodzaj wykonywanej pracy, szanse na przyszłość, wiek poszkodowanego, a także czynniki subiektywne, wśród których można wymienić poczucie nieprzydatności społecznej, bezradność życiową. Nie bez znaczenia są też takie okoliczności, jak pozbawienie możliwości osobistego wychowywania dzieci i zajmowania się gospodarstwem domowym, konieczność korzystania z pomocy innych osób przy prostych czynnościach życia codziennego ${ }^{37}$.

Za przyznaniem wysokiego zadośćuczynienia może przemawiać szczególne natężenie winy sprawcy szkody. Istotne znaczenie ma też wiek poszkodowanego oraz skutki doznanej krzywdy. Uznaje się bowiem, że krzywda osoby, u której urazy wywołały nieodwracalne dla zdrowia skutki i która nie może liczyć na ich ustąpienie w przyszłości, jest nieporównywalnie większa niż krzywda osoby, u której podobne skutki mają charakter przejściowy i ostatecznie przemijający. Różnica ta jest szczególnie istotna, gdy chodzi o osoby młode, które z racji wieku ze skutkami doznanych urazów będą się borykać przez wiele lat ${ }^{38}$.

Cywilnoprawna odpowiedzialność odszkodowawcza ma na celu uzyskanie naprawienia szeroko rozumianej szkody (a więc majątkowej i niemajątkowej) od podmiotu odpowiedzialnego, z tym zastrzeżeniem, że zdarzenie w postaci wypadku przy pracy (rodzące odpowiedzialność odszkodowawczą pracodawcy) nie może być źródłem wzbogacenia. Z tego względu konieczne jest uwzględnienie także czynników mających wpływ na obniżenie wysokości odszkodowania lub zadośćuczynienia, takich jak wypłacone już poszkodowanemu pracownikowi świadczenia na podstawie ustawy wypadkowej, orzeczenie przez sąd karny obowiązku naprawienia szkody lub przyznanie nawiązki (art. 46 k.k.) czy też przyczynienie się pracownika do powstania wypadku lub zwiększenia szkody (art. 362 k.c. w zw. z art. 300 k.p.).

W odniesieniu do pierwszego z wymienionych czynników warto zauważyć, że uwzględnienie świadczeń wypłaconych przez ZUS nie

37 Tak SN w wyroku z 18 kwietnia 2002 r., II CKN 605/00, «Legalis» nr 77418. 
oznacza obowiązku stosowania zasady compensatio lucri cum damno poprzez proste odejmowanie odszkodowania wypłaconego na podstawie przepisów ustawy wypadkowej od odszkodowania dochodzonego na podstawie przepisów kodeksu cywilnego. Subsydiarny charakter odpowiedzialności pracodawcy wyraża się jednak w tym, że przy ustalaniu wysokości odszkodowania należnego na podstawie przepisów kodeksu cywilnego świadczenia wypłacone z ustawy wypadkowej, a zwłaszcza jednorazowe odszkodowanie, powinny być wzięte pod uwagę przy określeniu wysokości zadośćuczynienia ${ }^{39}$.

Inaczej sytuacja wygląda, jeśli sąd karny w ramach rozpoznawania odpowiedzialności z tytułu przestępstwa orzekłby o obowiązku naprawienia szkody lub przyznałby nawiązkę. W takim wypadku zasądzone odszkodowanie lub przyznana nawiązka podlegają w całości zaliczeniu na poczet roszczeń pracownika ze względu na ich kompensacyjny charakter. Nie są to co prawda środki cywilnoprawne, ale ich istota polega na naprawieniu szkody. De lege lata sąd karny może, na podstawie art. 46 k.k., orzec jednocześnie o obowiązku naprawienia szkody i o zadośćuczynieniu albo z urzędu (fakultatywnie), albo na wniosek (obligatoryjnie). Ustawodawca pozostawia sądowi swobodę w zakresie wyboru środka penalnego, z jednoczesną możliwością uwzględnienia wniosków samego pokrzywdzonego. Należy podkreślić, że wytoczenie powództwa o naprawienie szkody, której ma dotyczyć wniosek, jest ujmowane jako przesłanka o charakterze negatywnym, która sprawia, że sąd karny nie może orzekać o środku prawnym z art. $46 \mathrm{k} . \mathrm{k} .{ }^{40}$ Uzasadnia to postawioną tezę o możliwości zaliczenia w całości zasądzonego odszkodowania lub przyznanej nawiązki na poczet roszczenia dochodzonego przez pracownika powództwem o naprawienie szkody powstałej w wyniku wypadku przy pracy.

39 Uchwała SN z 11 lutego 1963 r., II PO 6/62, «Lex» nr 104901. Por. też wyroki: SA w Łodzi z 25 marca 2015 r., III APa 2/15, «Legalis» nr 1285642, oraz SA w Gdańsku z 18 października 2013 r., III APa 32/13, «Legalis» nr 999090.

40 Por. A. GuzıK, Obowiązek naprawienia szkody w wybranych orzeczeniach Sadu Najwyższego, «Czasopismo Prawa Karnego i Nauk Penalnych» 2/2003, s. 99 i n. 
Kolejnym czynnikiem stwarzającym możliwość obniżenia odszkodowania jest przyczynienie się pracownika do powstałej szkody ${ }^{41}$. Stosownie do art. 362 k.c., jeżeli poszkodowany przyczynił się do powstania lub zwiększenia szkody, obowiązek jej naprawienia ulega odpowiedniemu zmniejszeniu stosownie do okoliczności, a zwłaszcza do stopnia winy obu stron ${ }^{42}$. Przesłanką stosowania art. 362 k.c. jest taki związek pomiędzy działaniem lub zaniechaniem poszkodowanego a powstałą szkodą (zwiększeniem się jej rozmiarów), że bez owej aktywności poszkodowanego bądź w ogóle nie doznałby on szkody, bądź wystąpiłaby ona w mniejszym rozmiarze. Przyczynieniem się do powstania szkody jest więc takie zachowanie poszkodowanego pracownika, które można zakwalifikować jako co najmniej obiektywnie nieprawidłowe ${ }^{43}$.

Na uwagę zasługuje dużo bardziej rygorystyczne rozwiązanie, które przewidział ustawodawca w art. 21 ust. 2 ustawy wypadkowej. W myśl art. 21 ust. 2 ustawy wypadkowej świadczenia $\mathrm{z}$ ubezpieczenia wypadkowego nie przysługują pracownikowi, który będąc $\mathrm{w}$ stanie nietrzeźwości lub pod wpływem środków odurzających lub substancji psychotropowych, przyczynił się w znacznym stopniu do spowodowania wypadku. Zgodnie z przyjętymi w ustawie wypadkowej rozwiązaniami przyczynienie się pracownika w znacznym stopniu do spowodowania wypadku przy pracy pozbawia go prawa do świadczenia, podczas gdy na gruncie kodeksu cywilnego może jedynie wpłynąć na przyjęcie wysokiego stopnia przyczynienia.

41 Wyrok SN z 15 kwietnia 1999 r., I CKN 1012/97, «Legalis» nr 44658.

42 Bliżej na temat sposobu obliczenia odszkodowania wyrównawczego w uwzględnieniu przyczynienia pracownika do powstania szkody J. BroL, Uprawnienia pracownicze w razie wypadku przy pracy i choroby zawodowej, Bydgoszcz 1991, s. 80 i n.

43 T. Wiśniewski, [w:] G. Bieniek, H. CiepŁa, S. DMowski, J. Gudowski, K. KoŁakowski, M. Sychowicz, T. Wiśniewski, Cz. ŻuŁawska, Komentarz do Kodeksu cywilnego. Księga trzecia. Zobowiązania, I, Warszawa 2011, s. 83 i n. 


\section{ODDALENIE POWÓDZTWA PRACOWNIKA W STOSUNKU DO} PRACODAWCY O ROSZCZENIA Z TYTUŁU WYPADKU PRZY PRACY

Uznanie zdarzenia za wypadek przy pracy nie oznacza automatycznie odpowiedzialności pracodawcy na zasadach określonych w kodeksie cywilnym. Wbrew pozorom reżim dochodzenia uzupełniających roszczeń odszkodowawczych według kodeksu cywilnego jest surowszy niż przesłanki uzyskania świadczeń z ustawy wypadkowej. Oznacza to, że pracownik, wytaczając powództwo przeciwko pracodawcy, powinien liczyć się także z ewentualną przegraną.

Przyczyn uzasadniających oddalenie powództwa pracownika w stosunku do pracodawcy może być wiele ${ }^{44}$. Warto jednak krótko przedstawić niektóre z nich.

W pierwszej kolejności sąd może oddalić powództwo ze względu na okoliczności wyłączające odpowiedzialność pracodawcy, na przykład wykazane przez pracodawcę przesłanki ekskulpacyjne (przy odpowiedzialności na zasadzie winy) czy też przesłanki egzoneracyjne (przy odpowiedzialności na zasadzie ryzyka) ${ }^{45}$. Mogą to być także te same przesłanki, które uzasadniałyby nieprzyznanie świadczeń z ustawy wypadkowej (art. 21), na przykład gdy wyłączną przyczyną wypadku przy pracy było udowodnione naruszenie przez pracownika przepisów dotyczących ochrony życia i zdrowia, spowodowane przez niego umyślnie lub wskutek rażącego niedbalstwa.

Kolejną okolicznością uzasadniającą oddalenie powództwa jest niesprostanie przez pracownika ciężarowi dowodu (onus probandi), objawiające się nieudowodnieniem dochodzonego roszczenia, przesłanek

44 Bliżej W. Broniewicz, Przyczyny oddalenia powództwa, «PiP» 19.5-6/1964, s. 834 i n.

45 Przesłankami wyłączającymi odpowiedzialność pracodawcy w przypadku odpowiedzialności ukształtowanej na zasadzie ryzyka jest powstanie szkody wskutek siły wyższej lub wyłącznie z winy poszkodowanego lub osoby trzeciej, za którą pracodawca nie ponosi odpowiedzialności. Jak wynika z orzecznictwa, pojęcie to nie obejmuje innych pracowników pracodawcy czy kontrahentów pracodawcy. Por. też R. SAdLIK, Zadośćuczynienie..., s. 469 i n. 
odpowiedzialności odszkodowawczej czy też zasadności lub wysokości dochodzonego roszczenia.

Na zakończenie należy także wspomnieć, że uchybienie materialnoprawnym terminom na dochodzenie roszczeń również uzasadniać będzie wydanie przez sąd wyroku oddalającego powództwo. Co do zasady, roszczenia ze stosunku pracy ulegają przedawnieniu z upływem trzech lat od dnia, w którym roszczenie stało się wymagalne (art. $291 \$ 1$ k.p.), $\mathrm{z}$ uwzględnieniem jednak rozwiązań $\mathrm{z}$ art. $442^{1} \mathrm{k}$.c. Jeśli bowiem szkoda wynikła ze zbrodni lub występku, roszczenie o naprawienie szkody ulega przedawnieniu $\mathrm{z}$ upływem lat $20 \mathrm{od}$ dnia popełnienia przestępstwa bez względu na to, kiedy poszkodowany dowiedział się o szkodzie i o osobie obowiązanej do jej naprawienia (art. $442^{1} \$ 2$ k.c.).

Warto też pamiętać, że ewentualnie wcześniej toczące się postępowanie karne lub postępowanie o sprostowanie protokołu wypadkowego bądź też postępowanie z odwołania od decyzji ZUS odmawiającej prawa do świadczenia ze względu na uznanie, że zdarzenie nie było wypadkiem przy pracy, nie przerywa biegu terminu przedawnienia, nie stanowi bowiem czynności w rozumieniu art. 123 k.c., mającej na celu dochodzenie lub ustalenie albo zaspokojenie lub zabezpieczenie roszczenia.

\section{Podsumowanie}

Na pracodawcy spoczywa generalny obowiązek zapewnienia pracownikom bezpiecznych warunków pracy i ma on charakter bezwzględny, a jego realizacja nie jest uzależniona od możliwości finansowych czy organizacyjnych pracodawcy.

Co istotne, niejednokrotnie pracodawcy trwają w błędnym przekonaniu, że odprowadzanie składek na ubezpieczenie wypadkowe zwalnia ich z odpowiedzialności za wypadek przy pracy. Oczywiście wypłacane z ustawy wypadkowej świadczenia, jak na przykład jednorazowe odszkodowanie, niewątpliwie minimalizują ujemne konsekwencje wywołane wypadkiem, ale nie stanowią swego rodzaju ubezpieczenia od odpowiedzialności cywilnej. 
Świadczenia przysługujące pracownikowi z ustawy wypadkowej nie zwalniają pracodawcy z odpowiedzialności za wyrządzoną pracownikowi szkodę, ale warto też podkreślić, że sama dopuszczalność dochodzenia roszczeń na zasadach określonych w kodeksie cywilnym nie przesądza uzupełniającej odpowiedzialności pracodawcy. Odpowiedzialność cywilnoprawna pracodawcy za wypadek przy pracy jest całkowicie odrębna od tej, którą ponosi Zakład Ubezpieczeń Społecznych na mocy ustawy wypadkowej. Odmienne są zasady i zakres tej odpowiedzialności.

Podsumowując, pożądane byłoby, aby pracodawca, realizując spoczywający na nim obowiązek zapewnienia pracownikom bezpiecznych warunków pracy, czynił to w dbałości o życie i zdrowie swoich pracowników, a nie li tylko, by uniknąć odpowiedzialności odszkodowawczej.

\section{CYWILNOPRAWNA ODPOWIEDZIALNOŚĆ ODSZKODOWAWCZA PRACODAWCY ZA WYPADEK PRZY PRACY}

\section{Streszczenie}

Pracownikowi w związku z wypadkiem przy pracy przysługują świadczenia z tzw. ustawy wypadkowej. Jeśli jednak przyznane świadczenia nie zaspokoiły roszczeń pracownika, to przysługują mu roszczenia uzupełniające w stosunku do pracodawcy, oparte na przepisach prawa cywilnego. Do ustalenia jednak odpowiedzialności odszkodowawczej pracodawcy za wypadek przy pracy konieczne jest wykazanie przez pracownika spełnienia przesłanek tej odpowiedzialności. Samo bowiem uznanie zdarzenia za wypadek przy pracy nie oznacza automatycznie, że zdarzenie to będzie rodziło cywilnoprawną odpowiedzialność pracodawcy. Artykuł ma na celu przybliżenie procesowych i materialnoprawnych aspektów związanych z dochodzeniem roszczeń pracownika w stosunku do pracodawcy oraz czynników mających wpływ na ich zakres. 


\section{The Employer's Civil Liability for Damages Due to an ACCIDENT AT Work}

\section{Summary}

Under the Polish Accident Act (ustawa wypadkowa) an employee who has an accident at work is entitled to certain benefits. However, if these benefits do not satisfy his claims, under Polish civil law he is entitled to supplementary claims against his employer. To prove the employer's liability for compensation, the employee has to show that the conditions for the employer's liability have been met. The recognition of the incident as an accident at work does not automatically mean that the employer is liable. The aim of this article is to present the procedural and substantive aspects of the employee's claims against his employer and the factors affecting their scope.

Słowa kluczowe: odpowiedzialność odszkodowawcza; wypadek przy pracy; uzupełniająca odpowiedzialność pracodawcy.

Keywords: civil liability; accident at work; the employer's complementary liability.

\section{Literatura}

Brol J., Odpowiedzialność odszkodowawcza za wypadki przy pracy i choroby zawodowe, Warszawa 1981, s. 183-185.

Brol J., Uprawnienia pracownicze $w$ razie wypadku przy pracy $i$ choroby $z a-$ wodowej, Bydgoszcz 1991, s. 60-61 i 80-82.

Broniewicz W., Przyczyny oddalenia powództwa, «PiP»19.5-6/1964, s. 831-840. Gersdorf M., Odpowiedzialność cywilnoprawna pracodawcy za wypadki przy pracy, «PiZS» 6/2003, s. 9-16.

GUZIK A., Obowiązek naprawienia szkody w wybranych orzeczeniach Sadu Najwyższego, «Czasopismo Prawa Karnego i Nauk Penalnych» 2/2003, s. 97-108. JаскоW IAK U., Wyrównywanie szkód niemajątkowych spowodowanych wypadkami przy pracy, Warszawa-Poznań 1975, s. 5-18 i 102-107.

JoŃCZyк J., Odpowiedzialność odszkodowawcza w prawie pracy, «PiP» 58.6/2003, s. 746-759.

JоŃсzYк J., Ubezpieczenie wypadkowe, «PiP» 58.6/2003, s. 3-15. 
LIszcz T., Glosa do wyroku SN z dnia 13 września 2016 r., III PK 146/15, «OSP» 5/2017, poz. 51, s. 122-129.

Liszcz T., Odpowiedzialność odszkodowawcza pracodawcy wobec pracownika, $c z .1$, «PiZS»12/2008, s. 2-12.

Liszcz T., Odpowiedzialność odszkodowawcza pracodawcy wobec pracownika, cz. 2, «PiZS» $1 / 2009$, s. 2-10.

Maniewska E., Jeszcze o odpowiedzialności cywilnoprawnej pracodawcy za wypadki przy pracy, «PiZS»12/2011, s. 20-23.

NARóG B., Odszkodowania za wypadki przy pracy w postępowaniach cywilnoprawnych, «Praca i Zdrowie» 3/2015, s. 48-49.

Ostaszewski W., Charakter odpowiedzialności uzupetniajacej pracodawcy a deliktowy reżim odpowiedzialności cywilnej, «PiZS» 6/2013, s. 2-7.

Raczkowski M., Kilka uwag o cywilnej odpowiedzialności odszkodowawczej pracodawcy, «PiZS» 4/2009, s. 2-7.

Raczкошsкi M., Zadośćuczynienie jako sankcja w odpowiedzialności kontraktowej z perspektywy prawa pracy, «PPH»12/2011, s. 52-54.

SADLIK R., Zadośćuczynienie $w$ razie wypadku przy pracy, «Monitor Prawa Pracy» 9/2014, s. 468-471.

Sanetra W., Nowa filozofia wypadkowa, «Przegląd Ubezpieczeń Społecznych i Zdrowotnych»11/2002, s. 2.

ŚLEBZAK K., Uzupelniajaca odpowiedzialność pracodawcy z tytułu wypadków przy pracy i chorób zawodowych, «PiZS» 11/2009, s. 2-10.

Wiśniewski T., [w:] G. Bieniek, H. Ciepea, S. Dmowski, J. Gudowski, K. KoŁakowski, M. Sychowicz, T. Wiśniewski, Cz. ŻuŁawska, Komentarz do Kodeksu cywilnego. Księga trzecia. Zobowiązania, I, Warszawa 2011, s. 83-89. 